\title{
DYNAMICS OF MUTUAL TRADE BETWEEN UKRAINE AND THE RUSSIAN FEDERATION IN THE CONTEXT OF CONFLICT'S IMPACT ON NATIONAL SECURITY: A CONCENTRATION-BASED APPROACH
}

\author{
Olga Oleshko'
}

\begin{abstract}
The purpose of the is to summarize and present the results of the study of economic prerequisites for the situation when trade between the aggressor (the Russian Federation) and the victim (Ukraine) was not stopped despite the conflict as well as to assess the dynamics of this trade in the context of indicators of national economic security of Ukraine. Methodology. The study is based on the analysis of International Trade Center data on exports and imports of Ukraine and the Russian Federation and mutual commodity flows for 2002-2019. In addition, the Herfindahl-Hirschmann index and the Linda index were calculated to determine the level of concentration of commodity and geographical structure of foreign trade. To assess the impact of the external sector on the level of economic security of Ukraine, indicators regulated by national legislation were evaluated such as economy openness, export coverage ratio of imports, times; share of the leading partner country in total exports of goods, share of the leading partner country in total imports of goods, share of the leading commodity (commodity group) in the total volume of goods exports, share of leading goods (commodity group) excluding energy imports in total imports of goods, share of raw materials and low degree of industrial export processing in total exports of goods, share of imports in domestic consumption, terms of trade index (price). Results of the survey showed that The Russian Federation was the largest trading partner, and remains a significant participant in Ukraine's foreign trade operations today. At the same time the objective process of reducing the importance of the Russian Federation in the export-import trade of Ukraine had begun long before 2014. Despite the fact that the level of danger in the foreign sphere has decreased to a certain extent, such an improvement occurs against the backdrop of the impossibility of completely terminating trade and other economic relations with the Russian Federation. Practical implications. Based on the analysis, the areas of overcoming risks in the external sphere should be recognized: strengthening the capacity of the domestic market, including the implementation of infrastructure renewal programs for transport facilities and military-industrial complex, stimulating foreign investment in mechanical engineering; stimulating foreign investment in high-technology activities; implementation of energy efficiency programs; simplifying administrative and tax conditions for the provision of service as a substitute to commodity trade. Value/originality. Data on concentration level of foreign trade of Ukraine and the Russian Federation and on level of foreign economic component of national economic security of Ukraine.
\end{abstract}

Key words: foreign trade, structure, concentration ratio, Linda Index, Herfindahl-Hirshman Index, Russia, Ukraine, conflict, international impact, national economic security.

JEL Classification: F12, F52, O19

\section{Introduction}

The conflict between the Russian Federation and Ukraine which turned into the open form in 2014 has many dimensions - political, military, information, economic etc. In addition, the experience of historical ties between the two countries, the imperfection of the world

Corresponding author:

${ }^{1}$ Classical Private University, Ukraine.

E-mail: olgaoleshko1984@gmail.com

ORCID: https://orcid.org/0000-0002-5416-6060 security system and the system of national security governance in Ukraine determined the specific, so-called hybrid, nature of this conflict. Such hybridization is also characterized by a multidimensional nature of forms and content, among which the paradoxical continuation of trade, investment and other economic relations 
between Ukraine and the Russian Federation occupies an important place. The purpose of the paper is to summarize and present the results of the study of economic prerequisites for the situation when trade between the aggressor (the Russian Federation) and the victim (Ukraine) was not stopped despite the conflict as well as to assess the dynamics of this trade in the context of indicators of national economic security of Ukraine.

\section{Literature review}

It should be noted that the problem of trade with the enemy is not new despite the fact that the hybridization of the conflict is considered as a modern phenomenon. Historical examples, on the one hand, were highlighted quite widely, for example, in the works of Barbieri, K., Levy, J. (1999, 2004), Geiger, T. (2008), Skonieczny A. (2018). Empirical generalizations of the prerequisites and circumstances of trade in latent and open conflict, the role of policy in trade relations were presented in the studies of Holsti K. (1986), Kinne, B. (2012), Mouritzen H. (2017), Oatley T. (2017). The issues of the research methodology that covers analysis of trade policy-making processes, security policy, the consequences of their implementation in the context of conflicts, and most importantly, the relationship of policy inefficiency with the consequences of conflict on trade relations were discussed by Mastanduno M. (1999), Mansfield E., Pollins B. (2001), Tang S. (2009).

At the same time, studies that directly or indirectly consider the economic prerequisites and consequences of the conflict between Ukraine and the Russian Federation (Stulberg A.N. (2012), Abdelal R. (2013), Johannesson, J., Clowes, D. (2020), Solchanyk, R. (2020)) pay more attention to global phenomena (energy policy, control over the gas transportation system, etc.) while the evaluation and analysis of trade relations themselves and their dynamics unfortunately remain out of sight.

\section{Survey methodology}

The role of bilateral trade in relations between countries at the stages of hidden conflict and its escalation up to open armed form is twofold. On the one hand, the interdependence of countries is a prerequisite for good-neighbourliness and deepening relations under normal conditions. On the other hand, the asymmetry of economic and political power between conflict actors creates incentives for a stronger actor to take advantage of its superiority to economically suppress a partner. Moreover, in a hybrid conflict economic interdependence often serves as ground for an inadequate response to aggression. In the case of Ukraine, it was lack of possibility to declare war since martial law means the cessation of trade, and under conditions of economic dependence this had and has a high risk of self-destruction of Ukrainian economy.

This raises two questions: what should serve as a measure to identify such interdependence and its graduation and how it affects the security of the country. The easiest answer to this questions is to assess the concentration of foreign trade of the countries participating in the conflict and formalize the assessment of foreign economic security.

Exports and imports' geographical and commodity structure concentration was assessed using the Herfindahl-Hirschmann approach:

$$
H H I=\sum_{i=1}^{n} s_{i}^{2},
$$

where $s_{i}$ is the share in the structure of exports/ imports, \%; in the analysis of geographical structure subscriptor $i$ refers to the case of a particular country; in the analysis of the commodity structure $s$ subscriptor i refers to the case of a particular commodity group.

Low concentration structures are characterized by $H H I<1000$; structures with a moderate concentration of $1000<H H I<1800$; structures with a high concentration of $1800<H H I<10.000$.

In order to better characterize the direction of trade flows in the geographical and nomenclature aspects, it is advisable to use the Linda index which for three factors is calculated using the following formula:

$$
I L=0,5 \cdot\left(\frac{s_{1}}{0,5 \cdot\left(s_{2}+s_{3}\right)}+\frac{0,5 \cdot\left(s_{1}+s_{2}\right)}{s_{3}}\right) \cdot 100,
$$

where $s_{1}, s_{2}, s_{3}$ are shares of the first, second and third factors with the highest weight in the structure.

In terms of $I L<120 \%$ the structure can be considered unconcentered, $120 \leq I L<200 \%$ moderately concentrated, and in terms of $I L \geq 200 \%$ concentrated.

The assessment of the level of foreign economic security before and after the deployment of the acute phase of the conflict was made in accordance 
with national guidance: the Methodological Recommendations for Calculating the Level of Economic Security of Ukraine, approved by Order of the Ministry of Economic Development and Trade of Ukraine No. 1277 of 29.10.2013. It includes several indicators as follows: Economy openness, \%; Export coverage ratio of imports, times; Share of the leading partner country in total exports of goods, \%; Share of the leading partner country in total imports of goods, \%; Share of the leading commodity (commodity group) in the total volume of goods exports, \%; Share of leading goods (commodity group) excluding energy imports in total imports of goods, \%; Share of raw materials and low degree of industrial export processing in total exports of goods, \%; Share of imports in domestic consumption, \%; Terms of Trade Index (Price), \%.

\section{Findings}

The results of the assessment of the concentration of merchandise exports and imports by geography are given in Table 1.

Based on them, the following can be noted.

1) The level of export concentration according to the IHH was quite low throughout the period under analysis. Values which were close to the lower limit of moderate concentration were noted in 2007-2011, and subsequently successively decreased, with a significant drop over the period of the acute phase of the conflict from 2013-2016, halved.

2) During the whole analyzed period, the three largest buyers of Ukrainian exports included the Russian Federation: its share in commodity exports increased from $17.6 \%$ in 2002 to $29.0 \%$ in 2011 , and after the beginning of the acute phase of the conflict in 2014, it decreased from $18.2 \%$ in 2014 to $6.5 \%$ in 2019, and for the first time in 2019 the Russian Federation was in 3rd place after China and Turkey. The second and third places in the top three importers of Ukrainian goods at different times were occupied by Turkey (2002, 2004-2015, 2017), Italy (2002-2003, 2005-2008, 2010-2011), Germany (2003-2004), China (2009, $2013,2015,2019)$. Total share of three importers exceeded 20\% in 2005-2014, while further exports' structures were more diversified.

3) At the same time, the Linda index indicates that the monopolistic position of the three largest importers from Ukraine was threatening until 2019, reaching its maximum level in 2011 ( $\mathrm{IL}=485.4 \%$ with a lower limit of excessive market power of the three countries of $200 \%$ ), although after the hot phase of the conflict, since 2015 and until 2018 it was in the field of moderate values.

Table 1

Indicators of concentration of geographical structure of Ukrainian exports/imports of goods

\begin{tabular}{|c|c|c|c|c|c|c|}
\hline \multirow{2}{*}{ Year } & \multicolumn{3}{|c|}{ Export of goods } & \multicolumn{3}{|c|}{ Import of goods } \\
\cline { 2 - 7 } & IHH & IL & $\begin{array}{c}\text { total share of the } \\
\text { top three partners }\end{array}$ & IHH & IL & $\begin{array}{c}\text { total share of the } \\
\text { top three partners }\end{array}$ \\
\hline 2002 & 496 & 282,4 & 29,1 & 1652,3 & 304,7 & 57,8 \\
\hline 2003 & 542,5 & 270,8 & 30,4 & 1636,9 & 371,1 & 55,1 \\
\hline 2004 & 510,3 & 258,8 & 29,3 & 1813,4 & 430,5 & 56,4 \\
\hline 2005 & 649 & 316,4 & 33,3 & 1500,1 & 363,9 & 52,4 \\
\hline 2006 & 692,2 & 293,4 & 35,3 & 1200,2 & 305,4 & 47,9 \\
\hline 2007 & 836,9 & 352,8 & 38,5 & 1049,6 & 279,6 & 45,2 \\
\hline 2008 & 718,9 & 383,3 & 34,8 & 794,9 & 269,1 & 37,7 \\
\hline 2009 & 614,5 & 424,7 & 30,4 & 1078 & 357,4 & 43,6 \\
\hline 2010 & 841,3 & 417,7 & 36,7 & 1541,8 & 384 & 51,8 \\
\hline 2011 & 992,1 & 485,4 & 38,9 & 1462,6 & 365,4 & 51,2 \\
\hline 2012 & 821,4 & 451,8 & 35,3 & 1309,9 & 317,6 & 49,7 \\
\hline 2013 & 746,2 & 403,7 & 34,1 & 1201,8 & 273,2 & 49,3 \\
\hline 2014 & 552,9 & 269,2 & 30,1 & 889,2 & 201,5 & 43,1 \\
\hline 2015 & 426 & 172,6 & 26,2 & 771,7 & 172,4 & 40,7 \\
\hline 2016 & 370,7 & 147 & 22,2 & 624,3 & 117,4 & 44 \\
\hline 2017 & 352,2 & 141,5 & 21,2 & 632,7 & 128,6 & 36,5 \\
\hline 2018 & 324 & 127,7 & 20,2 & 663,9 & 124,5 & 37,9 \\
\hline 2019 & 332,8 & 108 & 20,3 & 644,7 & 138,5 & 36,6 \\
\hline
\end{tabular}

Source: calculated on the basis of the International Trade Center data 
4) Peak points of concentration of the geographical structure of imports by $\mathrm{IHH}$ are 2004 and 2010. After that the IHH had a stable tendency to decline.

5) Total share of the three most important suppliers of goods to Ukraine was higher (36.6\%) than in exports $(30.3 \%)$. During the period 2002-2017, the main import partner was the Russian Federation, and its maximum significance $(36.5 \%$ of all imports) was determined in 2010; since 2011, the share of imports from the Russian Federation gradually decreased to $11.5 \%$ in 2019. In addition to the Russian Federation, Germany, as well as Turkmenistan (2002-2008) and China (20092019) were among the top three partners in imports.

6) Linda's index of concentration of the geographical structure of imports reached a maximum in 2004-2005 and 2010-2011.

The analysis of economic security risks for Ukraine arising from the mutual trade between Ukraine and the Russian Federation is impossible without assessing the commodity structure of exports and imports. Such an assessment was done taking into account the peculiarities of the dynamics of mutual trade. In particular, the following main intervals of dynamics were previously discovered: 2002-2008 - growth in trade volumes, 2009 - a decline associated with the global financial and economic crisis, 2010-2011 recovery in volumes, 2012-2016 - deterioration in the dynamics of mutual trade, 2019 - the year of trade decline after a slight recovery. Based on these intervals concentration indicators were calculated at 2002, 2008, 2009, 2011, 2016 and 2019.

Indicators of a commodity export structures concentration of Ukraine and the Russian Federation are shown in Table 2. Based on its data, the following can be said:

1) Level of concentration of the commodity structure according to the IHH in Ukraine is significantly lower than in the Russian Federation.

2) When taking into account standard commodity groups in exports, the Linda index indicates a decrease in the level of structure concentration in Ukraine: if in 2002 the gap between the most significant export position ("Iron and steel", 29.8\%) and the second ("Mineral fuels, mineral oils and products of their distillation...", 9.2\%) was 3.24 times, then in 2019 the gap between the leader (cereals, 19.3\%) and the second position ("Iron and steel", 17.5\%) is only 1.1 times. At the same time, the corresponding gaps between the leader ("Mineral fuels, mineral oils and products of their distillation...") and the second position ("Iron and steel") in the Russian Federation amounted to 10.4 and 12.2 times in 2002 and 2019, respectively.

If to analyze the commodity structure of mutual trade then it is worth dividing:

1) changes in the structure of mutual exports (that is changes in the shares of each commodity group in the volume of exports from Ukraine to the Russian Federation and imports from the Russian Federation); this allowed investigation of the changes in the commodity structure of geographically localized trade flows;

Table 2

Indicators of a commodity export structures concentration of Ukraine and the Russian Federation*

\begin{tabular}{|c|c|c|c|c|c|c|}
\hline Indicators & 2002 & 2008 & 2009 & 2011 & 2016 & 2019 \\
\hline \multicolumn{7}{|c|}{ Exports from Ukraine } \\
\hline $\mathrm{IHH}$ & 1132,77 & 1386,62 & 951,74 & 1014,75 & 847,72 & 931,94 \\
\hline$I L$ & 318,8 & 476,7 & 285,2 & 346,3 & 156,2 & 168,5 \\
\hline $\begin{array}{l}\text { Total share of the three most important commodity } \\
\text { groups with the highest weight in the structure }\end{array}$ & 46,1 & 46,0 & 41,8 & 41,1 & 45,3 & 46,3 \\
\hline \multicolumn{7}{|c|}{ Exports form the Russian Federation } \\
\hline$I H H$ & 2942,0 & 4429,4 & 4096,5 & 4741,3 & 2548,2 & 2961,1 \\
\hline$I L$ & 1043,3 & 1077,0 & 1285,7 & 476,2 & 944,0 & 1220,9 \\
\hline $\begin{array}{l}\text { Total share of the three most important commodity } \\
\text { groups with the highest weight in the structure }\end{array}$ & 68,6 & 71,8 & 67,9 & 82,4 & 52,2 & 56,8 \\
\hline
\end{tabular}

* Gray color indicates the cells in which the values of the indicators fell into the critical zone of the structure concentration according to the gradation scales of the indicators

** The classification category "Commodities not elsewhere specified" was among the product groups with the highest weight in the export structure of the Russian Federation; therefore, a formula for two factors was used to calculate the Linda index. 
2) changes in the weight of the Russian Federation in exports from Ukraine and imports to Ukraine for each commodity group; this allowed tracking the change in the role of the Russian Federation in foreign trade of Ukraine in the context of commodity groups.

Empirical data on structural changes in aggregate form are presented in Table 3. The concentration indicators shown in the table were calculated on a primary structure that did not undergo an aggregation.

As can be seen from the table, the concentration of the exports structure from Ukraine to the Russian Federation by IHH remains low, however, after the decline in the period 2011-2016, which includes the time of the acute phase of the armed conflict, for 2016-2019 there was an increase in concentration by almost 600 points.

The trend of the Linda index is about the same. However, it should be noted that in 2019, unlike 2016 , it was in the zone of moderate concentration risks due to the increased importance of three commodity groups ("Iron and steel", "Inorganic chemicals; organic or inorganic compounds of precious metals, of rare-earth metals, ..., "Machinery, mechanical appliances, nuclear reactors, boilers; parts thereof") of export to the Russian Federation in dynamics.

It is also important to understand that by the first and second of these commodity groups, Russia

Table 3

Commodity structure of exports from Ukraine to the Russian Federation and from the Russian Federation to Ukraine (shares of goods in the volume of geographically localized exports),\%, and its concentration indicators

\begin{tabular}{|c|c|c|c|c|c|c|}
\hline Commodity groups aggregates & 2002 & 2008 & 2009 & 2011 & 2016 & 2019 \\
\hline \multicolumn{7}{|c|}{ Ukraine's export of goods to the Russian Federation } \\
\hline Agro-industrial complex products & 20,4 & 12,2 & 16,3 & 10,2 & 1,9 & 2,0 \\
\hline Mineral resources & 2,8 & 8,3 & 9,3 & 16,1 & 3,7 & 5,2 \\
\hline Products of chemical and related industries & 12,0 & 7,8 & 9,7 & 8,6 & 15,9 & 28,8 \\
\hline Wood and articles of wood; wood charcoal & 6,3 & 4,0 & 6,6 & 4,2 & 6,2 & 3,3 \\
\hline Skins and products, textile products, footwear, etc. & 1,1 & 1,0 & 1,0 & 0,9 & 1,5 & 1,4 \\
\hline Building materials, precious metals and stones & 2,2 & 1,6 & 1,7 & 1,6 & 1,9 & 2,6 \\
\hline Iron and steel & 16,6 & 22,8 & 17,6 & 19,3 & 18,5 & 26,0 \\
\hline Non-ferrous metallurgy & 2,6 & 2,1 & 2,2 & 1,3 & 2,1 & 2,7 \\
\hline $\begin{array}{l}\text { Machinery, mechanical appliances, nuclear reactors, } \\
\text { boilers; parts thereof }\end{array}$ & 24,0 & 19,0 & 24,0 & 16,4 & 16,9 & 18,2 \\
\hline Vehicles & 10,1 & 19,3 & 8,5 & 19,4 & 4,1 & 7,7 \\
\hline Devices & 0,9 & 0,7 & 1,1 & 0,7 & 0,6 & 0,7 \\
\hline Other & 1,1 & 1,3 & 2,1 & 1,3 & 1,2 & 1,4 \\
\hline $\mathrm{IHH}$ & 706,8 & 776,2 & 665,0 & 868,1 & 572,9 & 1155,6 \\
\hline IL & 216,5 & 116,6 & 171,4 & 122,4 & 119,2 & 137,5 \\
\hline \multicolumn{7}{|c|}{ Ukraine's import of goods from the Russian Federation } \\
\hline Agro-industrial complex products & 2,2 & 3,9 & 4,0 & 2,5 & 0,9 & 0,5 \\
\hline Mineral resources & 66,3 & 46,2 & 64,2 & 68,7 & 39,3 & 59,6 \\
\hline Products of chemical and related industries & 5,9 & 10,2 & 10,5 & 8,1 & 25,1 & 14,0 \\
\hline Wood and articles of wood; wood charcoal & 2,9 & 2,4 & 2,3 & 1,6 & 4,2 & 3,1 \\
\hline Skins and products, textile products, footwear, etc. & 1,1 & 0,5 & 0,5 & 0,4 & 0,9 & 0,6 \\
\hline Building materials, precious metals and stones & 0,7 & 1,4 & 1,2 & 0,9 & 1,9 & 1,6 \\
\hline Iron and steel & 3,7 & 11,4 & 4,1 & 5,0 & 6,3 & 5,5 \\
\hline Non-ferrous metallurgy & 2,4 & 2,9 & 2,3 & 2,2 & 3,6 & 3,2 \\
\hline $\begin{array}{l}\text { Machinery, mechanical appliances, nuclear reactors, } \\
\text { boilers; parts thereof }\end{array}$ & 8,7 & 10,5 & 7,7 & 6,6 & 13,9 & 8,5 \\
\hline Vehicles & 5,1 & 8,8 & 2,1 & 3,2 & 2,9 & 2,5 \\
\hline Devices & 0,6 & 0,7 & 0,5 & 0,5 & 0,4 & 0,3 \\
\hline Інші & 0,2 & 0,9 & 0,5 & 0,3 & 0,6 & 0,6 \\
\hline $\mathrm{IHH}$ & 4245,5 & 2241,1 & 3908,8 & 4633,8 & 1654,5 & 3477,6 \\
\hline IL & 1018,0 & 415,8 & 1130,5 & 1195,6 & 275,7 & 869,3 \\
\hline
\end{tabular}

Source: calculated on the basis of the International Trade Center data 
and Ukraine are in a state of subject competition, and exports in the third group are very sensitive to political decisions of the Russian Federation.

The commodity structure of imports from the Russian Federation is concentrated much more: both concentration indicators show an excessive concentration of the import structure on mineral fuels, oil and oil products. And although the value of imports for this commodity group decreased by $80 \%$ compared to 2011 , it should be noted that in 2016-2019 this indicator still doubled, which indicates the objective difficulty of overcoming the dependence in such critical imports on the Russian Federation.

In the second aspect, attention should be paid to the following features.

Among commodity groups, in which exports to the Russian Federation account for more than half of the total export volume for the group from Ukraine in 2011 (the peak date of mutual trade relations before the outbreak of the conflict) are noted: meat and meat products; fish; dairy products, eggs and honey; cocoa products; alcoholic beverages; vegetable processing products; cork and articles of cork; salt, sulfur, limestone and cement; polymeric materials; paper, paperboard and products of the printing industry; carpet, umbrellas; stone and ceramic products; tin and articles thereof; machinery, mechanical appliances, nuclear reactors, boilers; railway or tramway locomotives, rolling stock and parts thereof; railway or tramway track fixtures. In 2019, there are only four such positions: cork and articles of cork (the Russian Federation accounts for $55.0 \%$ of all Ukrainian exports); nickel and articles thereof (53.2\%), inorganic chemistry products $(77.7 \%)$; lac, gums, resins and other vegetable saps and extracts (63.6\%).

Among commodity groups which exports to Ukraine account for more than $30 \%$ of all exports of the Russian Federation in such a group in 2011 are noted: dairy products, eggs and honey; tea, coffee, mate and spices (75\% of all exports of the Russian Federation); meat and fish products; pharmaceutical products; soap; plastics; cotton, other textile fibers; packaging fabrics; carpet (89\%); special fabrics; workwear; glass; lead and articles thereof; railway or tramway locomotives, rolling stock and parts thereof. In 2019, Ukraine's share in exports of the Russian Federation for specific commodity groups decreased significantly $-15 \%$ or more in the commodity structure accounted for only such groups as: meat (17\%), dairy products $(15.0 \%)$, fruits and nuts (15.1\%); pharmaceutical products (30\%); cotton (20.9\%), knitted or crocheted fabrics $(24.7 \%)$.

Regarding the role of the Russian Federation in the commodity structure of total imports of Ukraine, it was revealed that in 2011 more than $50 \%$ of all imports were accounted by the Russian Federation in such commodity groups as: mineral fuels, mineral oils and products of their distillation $(68.9 \%)$, fertilizers $(66.4 \%)$; weight of wood and cellulose (75.8\%); nickel and its products $(85.9 \%)$; lead and its products (80.9\%); railway rolling stock (58.4\%); in 2019, the share of the Russian Federation was higher than $40 \%$ by commodity groups: products of inorganic chemistry $(44.4 \%)$; pulp of wood or of other fibrous cellulosic material (57.4\%); nickel and articles thereof (71.6\%); lead and articles thereof (47.7\%); railway or tramway locomotives, rolling stock and parts thereof (40.9\%). In almost all critical groups of 2011 there was a decrease in the volume of dependence on the Russian Federation, and the share of mineral fuels from the Russian Federation amounted to only a third of all imports by Ukraine.

Table 4 presents the results of calculations of certain indicators of foreign economic security of Ukraine taking into account preliminary findings.

As can be seen from the data above, the number of indicators in a zone of critical, dangerous or unsatisfactory values has decreased. Some indicators shifted from the unsatisfactory zone to the interval between satisfactory and unsatisfactory levels.

Unfortunately, results of foreign economic risks analysis were not taken into account timely. And despite the fact that the level of danger in the foreign sphere has decreased to a certain extent, such an improvement occurs against the backdrop of the impossibility of completely terminating trade and other economic relations with the Russian Federation, since, as the analysis showed, not only the export/import of Ukraine as an economy with a significant level of openness, but also the state of development of a significant number of industries is sensitive to the role and policy of the Russian Federation.

\section{Conclusions}

A number of conclusions can be drawn from the analysis of the concentration and dynamics of the geographical structure of exports/imports. 
Table 4

Results of calculations of certain indicators of foreign economic security of Ukraine*

\begin{tabular}{|c|c|c|c|c|c|c|}
\hline Indicators & 2002 & 2008 & 2009 & 2011 & 2016 & 2019 \\
\hline Economy openness, \% & 79,4 & 81,0 & 70,0 & 92,5 & 81,0 & 71,8 \\
\hline Export coverage ratio of imports, times & 1,06 & 0,78 & 0,87 & 0,83 & 0,93 & 0,82 \\
\hline Share of the leading partner country in total exports of goods, $\%$ & 17,6 & 23,5 & 21,4 & 29,0 & 9,9 & 7,2 \\
\hline Share of the leading partner country in total imports of goods, $\%$ & 37,1 & 22,7 & 29,1 & 35,3 & 13,1 & 15,2 \\
\hline $\begin{array}{l}\text { Share of the leading commodity (commodity group) in the total } \\
\text { volume of goods exports, } \%\end{array}$ & 29,8 & 34,3 & 25,8 & 27,0 & 19,0 & 13,3 \\
\hline $\begin{array}{l}\text { Share of leading goods (commodity group) excluding energy } \\
\text { imports in total imports of goods, } \%\end{array}$ & 10,7 & 13,3 & 8,7 & 8,7 & 11,9 & 11,0 \\
\hline $\begin{array}{l}\text { Share of raw materials and low degree of industrial export processing } \\
\text { in total exports of goods, } \%\end{array}$ & 76,1 & 74,7 & 74,9 & 73,4 & 83,5 & 83,6 \\
\hline Share of imports in domestic consumption, $\%$ & - & 20,5 & 18,6 & 22,1 & 21,7 & 19,3 \\
\hline Terms of Trade Index (Price), \% & - & 100,1 & 73,8 & 104,1 & 99,8 & 99,9 \\
\hline
\end{tabular}

* Dark color indicates the cells in which values are at critical, dangerous and unsatisfactory levels; half-dark color shows cells in which values are located in the area between satisfactory and unsatisfactory values; cells without color indicate values at satisfactory or optimal levels.

The information basis for the calculation was the results of own studies as well as Ukrainian official statistics data.

The Russian Federation was the largest trading partner, and remains a significant participant in Ukraine's foreign trade operations today. In foreign trade there is a high level of dependence of Ukraine on goods from the main partners, in particular the Russian Federation, which creates prerequisites for sensitivity of the external sector of the national economy of Ukraine to the situation and economic policy in them. Such dependence was the most significant during the world financial and economic crisis of 2008-2010 and during the acute phase of the Russian-Ukrainian conflict. At the same time, it should be noted that the objective process of reducing the importance of the Russian Federation in the export-import trade of Ukraine had begun long before 2014. That indicates the duration of the process of accumulation of contradictions in mutual relations.

The result of the conflict and its hybrid nature were, first of all, a decrease in exports and export potential of Ukraine due to the loss of agricultural and production capacities in the annexed Crimea and temporarily occupied territories of eastern Ukraine, which worsened Ukraine's competitive position in international trade, an increase in risks for export of technological products and an increase in re-industrialization of exports. Despite the fact that the level of danger in the foreign sphere has decreased to a certain extent, such an improvement occurs against the backdrop of the impossibility of completely terminating trade and other economic relations with the Russian Federation.

Based on the analysis, the areas of overcoming risks in the external sphere should be recognized: strengthening the capacity of the domestic market, including the implementation of infrastructure renewal programs for transport facilities and military-industrial complex, stimulating foreign investment in mechanical engineering; stimulating foreign investment in high-technology activities; implementation of energy efficiency programs; simplifying administrative and tax conditions for the provision of service as a substitute to commodity trade.

\section{References:}

Barbieri, K., \& Levy, J. (1999). Sleeping with the Enemy: The Impact of War on Trade. Journal of Peace Research, 36(4), 463-479.

Barbieri, K., \& Levy, J. (2004). Trading with the enemy during wartime. Security Studies, 13(3), 1-47.

Geiger, T. (2008). Trading with the Enemy: Ireland, the Cold War and East-West Trade, 1945-55. Irish Studies in International Affairs, 19, 119-142.

Skonieczny, A. (2018). Trading with the enemy: narrative, identity and US trade politics. Review of International Political Economy, 25(4), 441-462. 
Holsti, K. (1986). Politics in Command: Foreign Trade as National Security Policy. International Organization, 40(3), 643-671.

Kinne, B. (2012). Multilateral Trade and Militarized Conflict: Centrality, Openness, and Asymmetry in the Global Trade Network. The Journal of Politics, 74(1), 308-322.

Mouritzen, H. (2017). Combining 'incompatible' foreign policy explanations: how a realist can borrow from constructivism. Journal of International Relations and Development, 20(3), 631-658.

Oatley, T. (2017). Open economy politics and trade policy. Review of International Political Economy, 24(4), 699-717.

Mastanduno, M. (1999). Economic statecraft, Interdependence, and national security: Agendas for research. Security Studies, 9(1-2), 288-316.

Mansfield, E. D., \& Pollins, B. M. (2001). The Study of Interdependence and Conflict. Journal of Conflict Resolution, 45(6), 834-859.

Tang, S. (2009). The Security Dilemma: A Conceptual Analysis. Security Studies, 18(3), 587-623.

Stulberg, A. N. (2012). Strategic bargaining and pipeline politics: Confronting the credible commitment problem in Eurasian energy transit. Review of International Political Economy, 19(5), 808-836.

Abdelal, R.(2013). The profits of power: Commerce and realpolitik in Eurasia. Review of International Political Economy, 20(3), 421-456.

Johannesson, J., \& Clowes, D. (2020). Energy Resources and Markets - Perspectives on the RussiaUkraine War. European Review, 1-20.

Solchanyk, R. (2020). Ukraine and Russia: From Civilized Divorce to Uncivil War. By Paul D’Anieri. Cambridge, Eng.: Cambridge University Press.

International trade statistics 2001-2019. Retrieved June 17, 2020, from: http://www.intracen.org /itc/ market-info-tools / trade-statistics/

Hirschman Albert, O. National Power and the Structure of Foreign Trade University of California Press. p. XIX. Retrieved June 15, 2020, from: https://dspace.gipe.ac.in/xmlui/bitstream/handle/ 10973/29303/GIPE-026809.pdf

Linda, R. Methodology of concentration analysis applied to the study of industries and markets, Commission of the European Communities, Brussels, 1976, 156 p. Retrieved June 15, 2020, from: https://core.ac.uk/download/pdf/5091475.pdf

Pro zatverdzhennia Metodychnykh rekomendatsii shchodo rozrakhunku rivnia ekonomichnoi bezpeky Ukrainy: nakaz Ministerstva ekonomichnoho rozvytku ta torhivli Ukrainy vid 29.10.2013 r. № 1277. Retrieved June 15, 2020, from: https://zakon.rada.gov.ua/rada/show/v1277731-13\#Text

Valovyi vnutrishnii produkt (1990-2019): ofitsiinyi vebsait Derzhavnoi sluzhby statystyky Ukrainy. Retrieved June 18, 2020, from: http://www.ukrstat.gov.ua/

Statystyka zovnishnoho sektoru Ukrainy za metodolohiieiu 6-ho vydannia «Kerivnytstva z platizhnoho balansu ta mizhnarodnoi investytsiinoi pozytsii» (MVF, 2009): ofitsiinyi vebsait Natsionalnoho banku Ukrainy. Retrieved June 19, 2020, from: https://bank.gov.ua/ua/statistic/sector-external/data-sectorexternal\#6

Tablytsia «vytraty-vypusk» (v tsinakh spozhyvachiv): ofitsiinyi vebsait Derzhavnoi sluzhby statystyky Ukrainy. Retrieved June 19, 2020, from: http://www.ukrstat.gov.ua/ 